\title{
A typology of education ballot issues: 1906 to 2009
}

\author{
Dick M. Carpenter II ${ }^{1, *}$, Wendi Clouse ${ }^{2}$ \\ ${ }^{1}$ Department of Leadership Research and Foundations, University of Colorado Colorado Springs, USA \\ \{dcarpent@uccs.edu\} \\ ${ }^{2}$ Department of Institutional Research, University of Colorado Colorado Springs, USA \{wclouse@uccs.edu\} \\ Received on 2 February 2013; revised on 5 February 2013; accepted on 14 March 2013; published on 15 July 2013
}

DOI: $10.7821 /$ naer.2.2.54-62

\begin{abstract}
Almost half of the states in the United States allow citizens to make educational policy through ballot issues, a mechanism of direct democracy. Yet, no study has attempted analyze the educational ballot issue landscape, meaning little systematic attention has been paid to this important and increasingly influential form of educational policy making. This study identifies and classifies the types of state ballot issues considered by voters in the 24 states that allow for the creation of educational policy through direct democracy. Between 1906 and 2009, citizens voted on 206 education-related ballot issues. Among these, six types emerged: curriculum and instruction, equity, fiscal, infrastructure, morality, and reform. Ballot issues have been used most often for fiscal issues, followed by infrastructure, reform, morality, and curriculum and instruction. Across all types of ballot issues, voters rejected education initiatives by a wide margin: A little more than $66 \%$ failed at the ballot box. Nevertheless, it remains a popular method of grassroots educational policymaking-2000 to 2009 saw the most frequent consideration of education ballot issues.
\end{abstract}

KEYWORDS: EDUCATIONAL POLICY, POLICY FORMATION, POLITICAL CAMPAIGNS, DEMOCRACY, POLITICS OF EDUCATION

\section{INTRODUCTION}

Almost half of the states in the U.S. allow voters to determine public policy through direct democracy in the form of ballot issues (also called initiatives, propositions, or questions). As research reported herein indicates, since 1906 more than 200 issues have been considered by voters on a variety of educational policy topics, ranging from higher education, to taxes, to school segregation, to the teaching of evolution, to Bible reading in schools. Yet, as of this writing, no study has attempted analyze the ballot issue landscape, specifically related to education over time. As a result, comparably little systematic attention has been paid to this important and increasingly influential form of educational policy making.

We respond to this need by analyzing all education ballot issues considered by voters across all 24 states that allow for the creation of educational policy through direct democracy. We find that between 1906 and 2009, citizens voted on 206 education ballot issues. Among these, six types emerged: curriculum and instruction, equity, fiscal, infrastructure,

*To whom correspondence should be addressed:

University of Colorado, PO Box 7150, Colorado Springs, CO 809337150 morality, and reform. The ballot issue has been used most often for fiscal policy issues (44.8\%), followed closely by infrastructure $(35.5 \%)$. A little more than $10 \%$ of the issues dealt with reform efforts, followed by equity $(3.9 \%)$, morality $(3 \%)$, and curriculum and instruction (2.5\%). Across all types of ballot issues, voters rejected education initiatives by a wide margin: A little more than $66 \%$ failed at the ballot box. Nevertheless, it remains a popular vehicle for attempting to shape the educational landscape - the period from 2000 to 2009 saw the most education ballot issues considered by voters. We conclude with how this typology could be used in further research related to educational policy not only in the United States but also in Europe, where direct democracy has enjoyed a long tradition.

The importance of this study is at least two-fold. First, while the legislative process has been the primary method of educational policymaking in the U.S., ballot initiatives have also played an important role and increasingly so in recent decades. Yet, the relative dearth of research on ballot issues in education means we do not fully understand this policymaking process. For example, what types of policies are pursued through direct democracy? How successful (defined as policy adoptions) have attempts at educational policymaking through ballot initiatives been? Second, analyzing policy consequences or outcomes is unquestionably important, but so too is understanding impulses in policymaking. This is particularly so with a process as broad as statewide ballot initiatives. This type of study contributes to a greater understanding of citizen's values, their priorities, and their policy preferences. Practically speaking, it also provides guidance on the efficacy of the ballot initiative as a tool for educational policy change, both broadly and by issue type. Given the resources necessary to implement a ballot initiative, this would prove particularly valuable.

\section{LITERATURE REVIEW}

Since the late $19^{\text {th }}$ and early $20^{\text {th }}$ century, initiative, referendum, and recall devices, mainly products of the Progressive Era, have been used - and increasingly so - by groups on both the left and right of U.S. politics to shape public policy (Cronin, 1989). The three are often confused: The popular initiative (used interchangeably with ballot issue in this writing) allows citizens to propose a legislative measure or constitutional amendment; the referendum is when a legislature refers a proposed or existing law to voters for approval or rejection; and the recall allows citizens to remove a public official by filing a petition bearing a specified number of signatures demanding a vote on that official's continued tenure in office. This paper's primary focus involves the state popular ballot initiative or issue (as 
opposed to referenda or recalls) and the types of policies that have been implemented historically via the direct democracy process. The issue process is also frequently used at the local level-such as with school district funding initiatives - but we focus our attention specifically on state-level education issues in this treatment.

Currently, 24 states allow for the ballot initiative process. South Dakota was the first state that adopted the statutory initiative and referendum in 1898, and Florida was the last in 1972, allowing popular initiatives for constitutional amendments (Dinan, 2007). Table 1 lists the states that allow for ballot issues and the year of origin of their direct democracy process (which is how the table is sorted).

Table 1. States that Allow for Ballot Issues

\begin{tabular}{cc}
\hline State & Year of Origin of Ballot Issue \\
\hline SD & 1898 \\
UT & 1900 \\
OR & 1902 \\
MT & 1904 \\
NV & 1905 \\
OK & 1907 \\
ME & 1908 \\
MI & 1908 \\
MO & 1908 \\
AR & 1910 \\
AZ & 1911 \\
CA & 1911 \\
CO & 1912 \\
ID & 1912 \\
NE & 1912 \\
OH & 1912 \\
WA & 1912 \\
MS & 1914 \\
ND & 1914 \\
MA & 1918 \\
AK & 1956 \\
WY & 1968 \\
IL & 1970 \\
FL & 1972 \\
\hline
\end{tabular}

Direct democracy is understood as the concept of allowing constituents the opportunity to create or modify state and local legislation or constitutional clauses. The initiative process was introduced during the Progressive Era by reformers who believed representative government had failed because legislatures were controlled by special interests. The idea was that with direct democracy citizens would regain some of the control that had passed to privileged interests and partisan politics (DuVivier, 2007). A comprehensive definition of the progressive expectation was created in 1912 with the publication of Government by All the People (Wilcox, 1912). The Wilcox text not only outlined what early proponents expected from the process, but served as an instrument to promote direct democracy. Wilcox focused on three main expectations for direct democracy: It would block political manipulation by special interest groups; the process would circumvent politicians who were protecting their self-interest; and it would give voice or agency to political ideas or proposals outside the purview of the current political elite or status quo.

Since the Wilcox book was published, the effects, efficacy, and implications of direct democracy have been widely explored (Bone \& Benedict, 1975; Clark, 1998; Colantuono, 1987; Dinan, 2007; DuVivier, 2007; Goebel, 1997; Hoesly, 2005; Magleby,
1998; Matsusaka, 1992; Matsusaka, 1995, 2004; Schacter, 1995; Sharum, 2007; Sittig, 1995; Skiba-Crafts, 2009). Within the literature related to the effects of direct democracy several dominant research themes associated with ballot issues are present. They include voter turnout, voter rights, campaign finance, how direct democracy alters legislative behavior, and economic influence on voting patterns.

Voter turnout literature encompasses a wide range of topics; however, mobilization of voters, motivation for turnout, and opinion change during election campaigns appear to be the most frequent topics addressed (Bone \& Benedict, 1975; Branton, Dillingham, Dunaway, \& Miller, 2007; McVeigh, 1995; Tolbert \& Smith, 2005). Voter rights is also a prevalent area of interest (Haider-Markel, Querze, \& Lindaman, 2007), and as in studies on voter mobilization and turnout, there are dominant subthemes in the voter rights research. These include (a) protecting against the "tyranny of the majority" within the context of direct democracy (Butler \& Ranney, 1978; Donovan \& Bowler, 1998; Frey \& Goette, 1998; Gerber, 1999), (b) the performance of minority rights within direct democracy elections (Donovan \& Bowler, 1998; Frey \& Goette, 1998; Gamble, 1997; HaiderMarkel et al., 2007), and (c) how direct democracy functions as a tool for social movements to establish their stakes in democratic institutions (Goldstone, 2004).

A third theme addresses how direct democracy alters legislative behaviors, such as agenda setting and voting patterns (Bowler \& Donovan, 1994; Bowler, Donovan, \& Tolbert, 1998; Branton, 2003; Dyck, 2009; Hadwiger, 1992; Magleby, 1984; Magleby, 1998; McCuan, Bowler, Donovan, \& Fernandez, 1998). This is a particularly popular research topic, given some of the aforementioned expectations of direct democracyblocking special interest manipulation, protecting against legislators' self-interests, and facilitating ideas and policies outside of the political status quo.

In addition to behavioral studies, considerable academic attention has focused on the relationship of voting and economic conditions (Bowler \& Donovan, 1994; Kramer, 1971; LewisBeck, 1990). National elections have been the primary object of study, but additional analyses have been performed to explore state level patterns (Chubb, 1988; Howell \& Vanderleeuw, 1990; Magleby, 1984; Peltzman, 1987). Most findings indicate that the state of the economy influences policy related ballot issues (Bowler \& Donovan, 1994).

Campaign finance regulation is another topic of inquiry within the literature (Carpenter, 2009; Edwards, 1995; Sittig, 1995; Stratmann, 2006). Public disclosure, campaign spending, and campaign reform fall under this general umbrella. During the past 25 years there has been greater interest in campaign finance, generally because of increased expenditures, alleged corruption, and promotion of equity.

Although the ballot issue literature is robust, few scholarly projects have explored the landscape of ballot issues over time. The notable exceptions include Branton's (2003) study of voting behavior on ballot propositions through two lenses. Branton first examined numerous issues across multiple states and then investigated which factors were associated with voting behaviors. The scope of the project utilized data on 50 ballot propositions in 1992, 1994, and 1996. The pool of initiatives included propositions across 20 states and concerned a variety of issues, such as term limits, abortion, gambling, gay rights, and taxes. The ballot propositions explored were grouped into three categories: economic/financial, term limits, and moral/social 
issues. Although the groupings were sufficient for the three years explored, a standardized typology was not the focus of the project.

In addition to Branton's work, Dyck (2009) explored political distrust and voting patterns. To do so, eight years of public opinion survey data on more than 30 separate ballot issues were used in a regression analysis. Dyck's research was an extension of work that explored the relationship of state fiscal patterns, influence of direct democracy, and voter's fiscal conservatism (Besley \& Case, 2003; Camobreco, 1998; Matsusaka, 1995, 2004); however, the study did not systematically group ballot issues.

These aforementioned works emerge from the political science literature and use general models to address the relevant themes of voting behavior, engagement, and direct democracy, yet they have not provided a typological framework applicable to this project. The same shortcoming is also true in educationspecific literature on ballot issues.

\subsection{Education-Specific Ballot Issue Studies}

In general, studies of education ballot issues are comprised of case studies and policy analyses, and the methods used are often descriptive in nature. The number of studies is also comparably sparse (comparable to the research on ballot issues cited above). The extant literature covers three broad areas: (a) the processes and contexts surrounding ballot issues, (b) the effects of ballot issues, and (c) factors that determine the outcome of educationrelated ballot issues.

Examples of the first include Olsen (2009), Mora (2009), and de Jong (2008), all of which examine ballot issues focused on English language programs. These case studies reveal that the context surrounding such prominent issues can be highly charged and dominated by advocacy groups whose interests transcend the specific question at issue in a ballot initiative. These case studies, and others (Moses \& Saenz, 2008), also demonstrate how educational issues come to be framed by advocacy groups and how such framing affects electoral outcomes.

Examples of the second area include de Jong, Gort, and Cobb (2005) and Towne, Wortley, Pratt, Margules, Carrasco, and Arasim (1994). The first, also focused on English language policies, analyzed how three medium-sized Massachusetts districts responded to the successful passage of an English-only ballot initiative. The second examined the effects of a 1994 ballot issue on school finance and educational reform in Michigan. Such studies represent important contributions to analyzing policies common across many states, although given the increase in the number of education ballot initiatives in recent decades, there are arguably too few of such studies.

The third type of research draws on the robust literature common in the political science discipline. Articles such as Bali (2008), Muir and Schneider (1999), and Whitney (1993) examine factors that contribute to the electoral success of education ballot initiatives. Such studies typically use quantitative analyses to ascertain significant determinants of voter support. Bali concludes that ideology and self-interest play a significant role in how people vote on bilingual education, school vouchers, and school funding. Muir and Schneider also examined school funding ballot issues and find that state electoral support of the creation of debt for public services is relatively high in general and that voters support education debt more readily than debt for most other policy needs. They find that voter support for education bonds is not related to current spending levels for education; the more a state uses the bond initiative process to fund public capital projects, the less likely voters are to support any given project and the cost or expense of a bond has little to do with voter support. In a study of school finance and initiatives in seven states-California, Nebraska, Oklahoma, Colorado, Missouri, North Dakota, and OregonWhitney shows that education finance measures enjoy greater passage rates when expenditures are directly tied to specific educational improvements that are carefully explained to the public. He also finds that broad public support and the type of tax also are important in voter approval.

Perhaps the research closest to what we report below comes from McLendon and Eddings (2002) who investigated the nature and scope of what they describe as the re-emergence of the statewide ballot phenomenon and its relationship and impact on the higher education policy domain. The purpose of the research was to apply a set of systematic procedures to describe the attributes of and to make valid inferences about ballot measures affecting higher education. The authors used a content analysis from a derived database to address four topical areas: the trends in type and frequency of higher education relevant ballot measures; the distinctive categories of ballot activity; the major ballot themes or issues within each category; and the passage rates of various kinds of measures. The database was created using all higher education relevant ballot measures from 1993 through 2000. Although related to the present study, it is limited in that it considers only higher education and examines only a seven-year period.

Articles like these represent important contributions to understanding the role of ballot issues in shaping educational policy, but the extant literature has only begun to examine this important policymaking vehicle. As Bali (2008) noted, "Clearly there is more work to be done to understand what kinds of education reforms emerge in the first place through the initiative process, why they emerge, and who benefits overall from their success" (p. 452). To that end, this article represents what we believe is an important foundational examination of education ballot issues. We begin with what Bali suggested as the first question-understanding what kinds of education policies emerge in the first place through the initiative process. In so doing, we create a typology of education ballot issues, examine their adoption over time, and discern their approval rates by voters.

\section{MATERIAL AND METHODS}

This study is guided by the following research question: Across all states that allow for ballot propositions and since the inception of ballot initiatives, what types of policy issues have been considered in ballot initiatives?

\subsection{Data}

The data for this study are all education ballot issues voted on across the 24 states that allow for this form of direct democracy. We collected the data from a database of ballot issues maintained by the National Conference of State Legislatures (NCSL; http://www.ncsl.org/default.aspx?tabid=16580). The database has a searchable web interface that allows users to filter issues by topic (education, agriculture, taxes, etc.), state, year, election cycle (primary, general, etc.), measure type (initiative, referendum, etc.), and keyword.

We limited our search only by topic (education) and measure type (initiative). All other fields allowed for the broadest 
possible results (i.e., all states, all years, all cycles, etc.). Search results included state, year, the ballot issue number and title as assigned by each state's secretary of state, a summary of the issue, whether the issue passed or failed, and the percentage of yes votes.

\subsection{Analyses}

We analyzed the data using standard qualitative coding procedures (Miles \& Huberman, 1994; Straus \& Corbin, 1998). First, the ballot issues were coded inductively by two independent coders using the constant comparative method (Glaser \& Strauss, 1967). This produced six primary codes or types (discussed in the results below) after standardizing similar coding schemes (e.g., where one coder used "taxation" and another used "tax revenue"). This was subjected to inter-rater reliability analysis using percent agreement and Cohen's Kappa (Cohen, 1960). Results indicated 88\% agreement and, according to Landis and Koch (1977), "almost perfect" (and significant) agreement as measured by Cohen's Kappa (Kappa=.88, $p=.000$ ). By type and overall, we also aggregated ballot issues by decade - facilitating a temporal examination of education ballot issues — and calculated passage rates.

\section{RESULTS}

\subsection{Descriptive Statistics}

Between 1906 and 2009, citizens in states that allow for ballot issues voted on 206 education-related ballot issues. Table 2 indicates which states considered education-related ballot issues and how many issues were considered per state. The state with the most issues was Oregon (33), followed closely by California (28). Three of the states saw no education-related ballot issuesIllinois, Mississippi, and Wyoming.

Table 2. Education Ballot Issues per State

\begin{tabular}{cc}
\hline State & Issues \\
\hline AK & 1 \\
AR & 18 \\
AZ & 13 \\
CA & 28 \\
CO & 18 \\
FL & 3 \\
ID & 1 \\
IL & 0 \\
MA & 3 \\
ME & 3 \\
MI & 11 \\
MO & 5 \\
MS & 0 \\
MT & 3 \\
ND & 18 \\
NE & 7 \\
NV & 4 \\
OH & 1 \\
OK & 15 \\
OR & 33 \\
SD & 4 \\
UT & 4 \\
WA & 13 \\
WY & 0 \\
\hline & \\
\hline
\end{tabular}

When aggregated by decade, most education ballot issues have been considered in the 2000-2009 decade, at almost twice the number of the next closest decade-1930-1939 (see Table 3 ). These arguably should be adjusted for the number of states that allowed for ballot issues in a given decade, since, for example, only nine states allowed ballot issues in the first decade measured here and all 24 allowed for them in the first decade of the $21^{\text {st }}$ century. Even after making such an adjustment, the trend looks essentially the same. Earlier decades saw frequent use of the ballot initiative process for the consideration of educational policies, followed by a drop in rate through the 1970s. After that, one observes an increase in frequency to a high-point in the 2000 s of almost two initiatives per state.

Table 3. Issues by Decade

\begin{tabular}{cccc}
\hline Year & Frequency & Percent & Issues per State \\
\hline $1900-1909$ & 2 & 0.97 & 0.22 \\
$1910-1919$ & 21 & 10.19 & 1.05 \\
$1920-1929$ & 22 & 10.68 & 1.1 \\
$1930-1939$ & 23 & 11.17 & 1.15 \\
$1940-1949$ & 20 & 9.71 & 1 \\
$1950-1959$ & 17 & 8.5 & 0.8 \\
$1960-1969$ & 14 & 6.8 & 0.63 \\
$1970-1979$ & 12 & 5.83 & 0.5 \\
$1980-1989$ & 13 & 6.31 & 0.54 \\
$1990-1999$ & 19 & 9.22 & 0.79 \\
$2000-2009$ & 43 & 20.87 & 1.79 \\
\hline
\end{tabular}

\subsection{Across all states that allow for ballot} propositions and since the inception of ballot initiatives, what types of policy issues have been considered in ballot initiatives?

Among the 206 ballot issues, six types emerged: curriculum and instruction, equity, fiscal, infrastructure, morality, and reform. Of these, the ballot issue has been used most often for fiscal policy issues $(44.8 \%)$, followed closely by infrastructure (35.5\%). A little more than $10 \%$ of the issues dealt with reform efforts, followed by equity (3.9\%), morality (3\%), and curriculum and instruction (2.5\%).

\subsubsection{Fiscal}

The vast majority- $86 \%$ - of fiscal ballot issues dealt with school funding, specifically how and to what degree schools would be funded (taxes, bonds, etc.). In one group of these issues, voters typically considered whether to designate or increase funds for educational programs or institutions. For example, Washington voters in 2004 saw Issue 884, which would have increased sales tax rates by $1 \%$, the revenues of which would have been used to create a special fund for various educational uses. Likewise, Ohio's Issue 1, in 1965, would have increased taxes for a school foundation program. Not surprisingly, this was a common theme among early ballot issues, such as a 1916 issue in Arkansas that raised the minimum school district tax from seven to 12 mills and a 1920 Colorado issue that provided an additional one-mill levy for state education institutions.

The opposite impulse was also true-where initiatives were designed to limit or reduce school funding in some wayalthough not nearly as often. In 2005, California's Proposition 76 would have limited state spending on education to the prior year's level plus three previous years' average revenue growth. North Dakota voters rejected a 1940 issue (7P) that would have 
reduced the state per-pupil payment to schools and increased emergency funds for schools in distress.

Some issues addressed the source of revenue for education. For example, Minnesota's Proposal C, in 1972, would have limited property taxes for school, county, and township purposes and required the legislature to establish a state tax program for support of schools. Missouri voters considered a similar proposal (also titled Proposition C) in 1982, but unlike in Minnesota, it passed in Missouri.

As Table 4 indicates, school funding ballot issues generally appeared to be more frequently used in earlier decades. Whether measured in percentage terms or in issues per state per decade, the period of 1940 to 1949 saw the most fiscal issues. And aside from the 2000-2009 period, decades beginning with the 1950s tended to see the smaller percentages and the smaller number of issues per state.

Table 4. Fiscal Ballot Issues by Decade

\begin{tabular}{cccc}
\hline Year & Frequency & Percent & Issues per State \\
\hline $1900-1909$ & 1 & 1,27 & 0,11 \\
$1910-1919$ & 9 & 11,39 & 0,45 \\
$1920-1929$ & 7 & 8,86 & 0,35 \\
$1930-1939$ & 9 & 11,39 & 0,45 \\
$1940-1949$ & 15 & 18,99 & 0,75 \\
$1950-1959$ & 5 & 6,33 & 0,24 \\
$1960-1969$ & 4 & 5,06 & 0,18 \\
$1970-1979$ & 5 & 6,33 & 0,21 \\
$1980-1989$ & 6 & 7,59 & 0,25 \\
$1990-1999$ & 4 & 5,06 & 0,17 \\
$2000-2009$ & 14 & 17,72 & 0,58 \\
\hline
\end{tabular}

The remaining fiscal ballot issues addressed a potpourri of educational issues. Three of them-one each in California, Colorado, and Washington-dictated how educational funds could be used. For example, Colorado's Amendment 39 would have required that $65 \%$ of school funds be used "in the classroom," and California's Proposition 223 would have imposed limitations on how much educational funding could be dedicated to administration.

Two of the fiscal issues addressed student fees in higher education, one of which would have enabled the creation of fees (Oregon's Measure 4 in 1936) and the other of which would have changed how fees were authorized in Massachusetts (1994's Question 3). Another two issues-both in North Dakota - asked voters to consider student loan policies. The first created a student loan fund in 1956, and the second (in 2002) would have allowed for reimbursements on student loans and the creation of income tax credits for state residents. Still another two issues addressed teacher compensation. Arkansas voters in 1962 rejected an initiative related to a teacher retirement fund, and Washington voters approved in 2000 an issue that provided automatic annual cost-of-living increases for school district employees.

Of the final three fiscal ballot issues, the first chronologically was a 1916 amendment to Colorado's constitution, approved by voters, which provided for the investment of school funds into "certain securities." The second, which also passed, was 1970's Proposal C in Michigan that prohibited public aid to nonpublic schools and students. The final issue was a 2002 California proposition that increased state grant funds for before and after school programs. Voters also approved this ballot issue.

Taken together, most fiscal issues failed in the ballot box. Only $38.5 \%$ of all fiscal ballot issues passed. Moreover, as Table
5 indicates, the pass rates varied substantially over time. While several decades saw no fiscal issues pass, the first decade of the $21^{\text {st }}$ century saw slightly more pass than fail, and the decade of the 1940s saw almost three times as many fiscal issues pass than fail.

Table 5. Pass Rates for Fiscal Issues

\begin{tabular}{ccc}
\hline Year & Fail & Pass (\%) \\
\hline $1900-1909$ & 0 & $1(100 \%)$ \\
$1910-1919$ & 6 & $4(40 \%)$ \\
$1900-1929$ & 4 & $3(43 \%)$ \\
$1930-1939$ & 10 & $0(0 \%)$ \\
$1940-1949$ & 4 & $11(73 \%)$ \\
$1950-1959$ & 3 & $3(50 \%)$ \\
$1960-1969$ & 5 & $0(0 \%)$ \\
$1970-1979$ & 5 & $1(17 \%)$ \\
$1980-1989$ & 4 & $2(33 \%)$ \\
$1990-1999$ & 6 & $0(0 \%)$ \\
$2000-2009$ & 9 & $10(53 \%)$ \\
\hline
\end{tabular}

\subsubsection{Infrastructure}

This type of ballot issue addresses the creation, organization, and maintenance of educational structures and systems. The majority of these $(80.5 \%)$ dealt with either the creation of systems and structures or their reorganization. Ballot issues that created new systems and structures were most often considered in the earlier decades included herein. In fact, $72 \%$ of these ballot issues were considered prior to 1940 . Such issues created public school systems, community college systems, state boards of education, school funding systems, compulsory education, normal schools, teacher examination requirements, accountability systems, and higher education boards of trustees. Ballot issues considered by voters in more recent years most often concerned the creation of early childhood opportunities.

Although most "creation" ballot issues were considered prior to 1940 , the opposite was true for issues focused on reorganization. Seventy-two percent of reorganization issues came after 1949. These issues typically dealt with moving or renaming universities and normal schools, changing how state boards and chief state school officers were selected, school district consolidation, and even two issues in South Dakota (one in 1984 and the other in 2006) that prohibited schools from starting before Labor Day and the last day of August respectively.

Of the remaining infrastructure ballot issues, two sub-types were prevalent - those addressing textbooks in schools and others focused on personnel-related policies. The five textbook ballot issues were all considered in Oklahoma and Arkansas prior to 1946, typically dealt with the provision of free textbooks to schools, and all failed except Oklahoma's Question 318 in 1946. The six personnel-related issues dealt with the position of county superintendents in Oklahoma and teacher training, certification, tenure, and retirement. Four of the six were considered prior to 1943, and the latest-California's Proposition 72 on teacher tenure-failed in 2005.

As with fiscal ballot issues, most infrastructure initiatives failed. Only $30 \%$ of all infrastructure issues passed. As Table 6 indicates, the pass rates tended to be around that $30 \%$ figure across numerous decades, with just a few exceptions from 1900$1909,1940-1949$, and the 1990s. 
Table 6. Infrastructure Pass Rate

\begin{tabular}{ccc}
\hline Year & Fail & Pass (\%) \\
\hline $1900-1909$ & 0 & $1(100 \%)$ \\
$1910-1919$ & 9 & $2(18 \%)$ \\
$1900-1929$ & 7 & $4(36 \%)$ \\
$1930-1939$ & 7 & $2(22 \%)$ \\
$1940-1949$ & 1 & $3(75 \%)$ \\
$1950-1959$ & 7 & $2(22 \%)$ \\
$1960-1969$ & 6 & $3(33 \%)$ \\
$1970-1979$ & 4 & $1(20 \%)$ \\
$1980-1989$ & 1 & $0(0 \%)$ \\
$1990-1999$ & 7 & $3(30 \%)$ \\
$2000-2009$ & 0 & $1(100 \%)$ \\
\hline
\end{tabular}

\subsubsection{Reform}

Of all the ballot issue types, reform initiatives are among the most consistent in sub-type and time. Of the 21 reform issues, 15 are related to school choice. The rest focus on merit pay (2), reducing class sizes (2), state assessments for students (1), and one anti-reform initiative. All but two of these were considered after 1987.

The school choice issues included the dominant choice forms-vouchers, charter schools, and tax credits-but two issues appeared to be designed to facilitate subsequent choice efforts. The first chronologically was a 1976 Missouri issue that would have provided textbooks and other services to students in public and nonpublic schools. This failed $60 \%$ to $40 \%$. The second was a 1996 Colorado initiative that would have amended the state constitution to declare parents have the natural, essential, and inalienable right to direct and control the upbringing, education, values, and discipline of their children. Similar to Missouri, this failed $58 \%$ to $42 \%$. In fact, none of the school choice ballot issues passed, and only one-a charter school initiative in Washington in 2000 - ever enjoyed greater than $42 \%$ support by voters.

\subsubsection{Equity}

The equity ballot issues focus on issues of equal opportunities for students. Most often, these initiatives concerned how students were assigned to public schools. The earliest of these issues was considered in 1950 (a segregation-related initiative in Arizona that failed) and the most recent was a 2006 Michigan ballot issue on affirmative action, which passed. Of the eight equity issues, five were approved by voters.

\subsubsection{Morality}

Ballot issues of this type focused on four concerns: banning the teaching of evolution in schools (1928 in Arkansas), requiring the presence of or reading from the Bible in public schools (California in 1926 and Arkansas in 1930), prohibiting teachers from wearing religious dress in public schools (North Dakota in 1948), and prohibiting public school instruction that encouraged, promoted, or sanctioned homosexuality or bisexuality (California in 1978 and Oregon in 2000). The two issues concerning the Bible and the North Dakota issue on religious dress all passed. The rest did not.

\subsubsection{Curriculum and Instruction}

The final ballot issue type-curriculum and instructionconcerns the content or methods of teaching and learning in schools. In this type, only one topic has been the subject of all five ballot issues-language of instruction. Beginning in 1998, voters in Arizona, California, Colorado, Oregon, and Massachusetts considered initiatives that required or would have required that English language learners be taught in English immersion programs rather than in bilingual classrooms. These initiatives passed in three of the states-Arizona, California, and Massachusetts - and with strong support. None passed with less than $60 \%$ in the affirmative.

\subsubsection{Ballot Issue Status}

When all ballot issues are taken together, the majority failed in the ballot box. A little more than $66 \%$ of the ballot issues were rejected by voters. As Table 7 indicates, the percentage of issues that passed over time varied substantially by decade. Removing 1900-1909 from the list, given only two issues were considered that decade, the high water mark was the 1940 s, during which $75 \%$ of education ballot issues were approved. The next highest was $2000-2009$, which saw $40 \%$ of issues pass. Interestingly, the low water make came just before the 2000 s, when the last decade of the $20^{\text {th }}$ century saw only one education ballot issue pass.

Table 7. Pass Rates for All Education Ballot Issues

\begin{tabular}{ccc}
\hline Year & Fail & Pass (\%) \\
\hline $1900-1909$ & 0 & $2(100 \%)$ \\
$1910-1919$ & 15 & $6(28 \%)$ \\
$1900-1929$ & 14 & $8(36 \%)$ \\
$1930-1939$ & 17 & $4(19 \%)$ \\
$1940-1949$ & 5 & $15(75 \%)$ \\
$1950-1959$ & 11 & $6(35 \%)$ \\
$1960-1969$ & 11 & $3(21 \%)$ \\
$1970-1979$ & 8 & $4(33 \%)$ \\
$1980-1989$ & 10 & $3(23 \%)$ \\
$1990-1999$ & 18 & $1(5 \%)$ \\
$2000-2009$ & 26 & $17(40 \%)$ \\
\hline
\end{tabular}

\section{DISCUSSION AND CONCLUSION}

This study sought to identify and classify the types of state ballot issues that have been considered by voters in the 24 states that allow for the creation of educational policy through direct democracy. Between 1906 and 2009, citizens in states that allow for ballot issues voted on 206 education-related ballot issues. Among these, six types emerged: curriculum and instruction, equity, fiscal, infrastructure, morality, and reform. The ballot issue has been used most often for fiscal policy issues (44.8\%), followed closely by infrastructure at $35.5 \%$. A little more than $10 \%$ of the issues dealt with reform efforts, followed by equity $(3.9 \%)$, morality (3\%), and curriculum and instruction $(2.5 \%)$. Finally, across all types of ballot issues, voters rejected education initiatives by a wide margin: A little more than $66 \%$ failed at the ballot box. Nevertheless, it remains a popular method of grassroots educational policymaking -2000 to 2009 saw the most frequent consideration of education ballot issues.

That failure rate is generally consistent with prior research indicating the difficulty associated with the passage of ballot issues generally. Voters tend to default to "no" when voting on issues, and overcoming such inertia is daunting for issue committees and supporters (Bowler \& Donovan, 1998). Particularly striking here, however, is that the majority of the education ballot issues were not what might be considered controversial. Almost 45\% were fiscal issues, and a little more than $35 \%$ were infrastructure. Yet, even such "nuts and bolts" 
issues enjoyed limited support, which should strike a note of caution for groups interested in pursuing new state educational policies through the initiative process.

Indeed, these results indicate that educational policymaking in the U.S. through direct democracy is no guaranteed way of circumventing legislatures, as Wilcox (1912) described one of direct democracy's purposes. Such results related to direct democracy are consistent with other policymaking processes in the U.S. As Birkland (2011) notes, the policy and political structure of the United States makes significant policy change difficult. "For those interested in policy change, the structure is troubling, for it suggests that mass movements and participatory democracy are not likely to carry the day in policy debates" (p. xiii). Not only are U.S. policy structures resistant to change, so too is the general public. Page and Shapiro (1992) studied policy preferences in the U.S. during much of the $20^{\text {th }}$ century (overlapping significantly with the period covered in this article). They found policy preferences were quite stable, and significant changes came only after a critical mass of consensus was achieved about a perceived need for change.

The fact that groups have used the initiative process primarily for educational fiscal and infrastructure policies also seems somewhat at odds with another of the intents or expectations of ballot issues (Wilcox, 1912). As discussed above, one of those was that direct democracy would give voice or agency to political ideas or proposals that were outside the purview of the current political elite or status quo. If so, one might expect to see fewer fiscal issues, for example, and a greater number of reform, equity, or morality initiatives, but that was not the case by a wide margin. Yet, closer examination of the timing of certain initiatives indicates the comparatively smaller number of issues - such as those related to school reform, for examplemay be understood by the social, policy, and educational context. Moreover, despite what these results appear to show at first glance, direct democracy may, in fact, present "outside" interests an avenue to attempt policy change.

By way of illustration, school reform in the U.S. did not become a salient issue until the 1980s (Carpenter \& Kafer, 2012). Although there was some acknowledgment that schools in certain areas (e.g. urban centers) were struggling, it was not until the release of $A$ Nation at Risk (The National Commission on Excellence in Education, 1983) that widespread perception of school failure took hold. Commissioned by U.S. Secretary Terrell Bell, A Nation at Risk pointed to declining test scores and international comparisons to conclude, "[T]he educational foundations of our society are presently being eroded by a rising tide of mediocrity that threatens our very future as a Nation and a people" (p. 5). The report gained nationwide attention and was followed by legislative reform efforts. Prior to A Nation at Risk, school reform-particularly choice-was a fringe issue and strongly opposed by the educational establishment, but with a growing perception of school failure, reform ideas took on new salience (Carpenter \& Kafer, 2012). The educational establishment, however, continued to oppose reform vigorously in state legislatures, making ballot issues a more attractive vehicle of policy change. Indeed, almost all of the reform ballot initiatives in our dataset were introduced in the 1980s and after. This, then, contributes to a greater understanding of why there are relatively fewer reform-related ballot issues-it did not become a salient issue until just recently. However, if the example of reform initiatives illustrates how policy outsiders use ballot issues to attempt policy change, it also confirms Birkland (2011) and Page Shapiro's (1992) observations about policy stability - all but one of the reform initiatives in our dataset failed at the ballot box.

Where this research provides important insight into the predilections and preferences of Americans in educational policymaking, it "sets the table" for several future and important studies. First, it would be revealing to examine the relationship between types of educational policies pursued through direct democracy and legislation adopted by elected officials. Similar to Bowler and Donovan (1994), Bowler, Donovan, and Tolbert (1998), Branton (2003), and others (Dyck, 2009; Hadwiger, 1992; Magleby, 1984; Magleby, 1998; McCuan et al., 1998), this would test the general hypothesis that direct democracy may alter legislative behavior regarding educational policy making.

Second, the typology reported herein also would facilitate an examination of factors that predict the pursuit and/or electoral success of certain types of ballot issues, similar to some of the research noted above (Bone \& Benedict, 1975; Bowler \& Donovan, 1994; Branton et al., 2007; McVeigh, 1995; Tolbert \& Smith, 2005). Given preference for policy stability and structural barriers to policy change through participatory democracy, what factors contribute to the pursuit of certain types of educational policies? Moreover, what contributes to educational policymaking success (defined as policy adoption) through direct democracy? This would be particularly important to know given the increased popularity and use of ballot initiatives in recent decades.

Finally, future research could expand the scope of this treatment beyond the borders of the U.S. and compare these results (among other things) to education initiatives in Europe, which has seen direct democracy for more than 200 years (Kaufmann $\&$ Waters, 2004). Such research could examine, for example, if education ballot issues in Europe fall into the same types, what types of educational policies are more prevalent, and how successful education issues are in the ballot box.

\section{REFERENCES}

Bali, V. A. (2008). The passage of education citizen initiatives: Evidence from California. Educational Policy, 22(3), 422-456. doi:10.1177/0895904807307066

Besley, T., \& Case, A. (2003). Political institutions and policy choices: Evidence from the United States. Journal of Economic Literature, 41(1), 7-73. doi: 10.1257/002205103321544693

Birkland, T. A. (2011). An introduction to the policy process: Theories, concepts, and models of public policy making (3rd ed.). Armonk, NY: M.E. Sharpe.

Bone, H. A., \& Benedict, R. C. (1975). Perspectives on direct legislation: Washington State's experience 1914-1973. Political Research Quarterly, 28, 330-351. doi:10.1177/106591297502800208

Bowler, S., \& Donovan, T. (1994). Information and opinion change on ballot propositions. Political Behavior, 16, 411-435. doi:10.1007/BF01498825

Bowler, S., \& Donovan, T. (1998). Demanding choices: Opinion, voting, and direct democracy. Ann Arbor, MI: University of Michigan Press.

Bowler, S., Donovan, T., \& Tolbert, C. (1998). Citizens as legislators: Direct democracy in the United States. Columbus, OH: Ohio State University Press.

Branton, R., Dillingham, G., Dunaway, J., \& Miller, B. (2007). Anglo voting on nativist ballot initiatives: The partisan impact of spatial proximity to the U.S.-Mexico border. Social Science Quarterly, 88(3), 882-898. doi: 10.1111/j.1540-6237.2007.00488.x

Branton, R. P. (2003). Examining individual-level voting behavior on state ballot propositions. Political Research Quarterly, 56(3), 367377. 
Butler, D., \& Ranney, A. (1978). Theory. In D. Butler \& A. Ranney (Eds.), Referendums: A comparative study of practice and theory (pp. 23-37). Washington, DC: American Enterprise Institute.

Camobreco, J. F. (1998). Preferences, fiscal policies, and the initiative process. Journal of Politics, 60, 819-829. doi:10.2307/2647650

Carpenter, D. M. (2009). Mandatory disclosure for ballot-initiative campaigns. Independent Review, 13(4), 567-583.

Carpenter, D. M., \& Kafer, K. (2012). A history of private school choice. Peabody Journal of Education, 87, 336-350. doi:10.1080/0161956X.2012.679587

Chubb, J. (1988). Institutions, the economy, and the dynamics of state elections. American Political Science Review, 82, 133-152. doi: $10.2307 / 1958062$

Clark, S. J. (1998). A populist critique of direct democracy. Harvard Law Review, 112(2), 434-482. doi: 10.2307/1342426

Cohen, J. (1960). A coefficient of agreement for nominal scales. Educational and Psychological Measurement, 20, 37-46. doi:10.1177/001316446002000104

Colantuono, M. G. (1987). The revision of American state constitutions: Legislative power, popular sovereignty, and constitutional change. California Law Review, 75(4), 1473-1512. doi:10.2307/3480598

Cronin, T. E. (1989). Direct democracy. The politics of initiative, referendum and recall. Cambridge, MA: Harvard University Press.

deJong, E. J. (2008). Contexualizing policy appropriation: Teachers' perspectives, local responses, and English-only ballot intitiatives. Urban Review: Issues and Ideas in Public Education, 40(4), 350370 .

deJong, E. J., Gort, M., \& Cobb, C. D. (2005). Bilingual education within the context of English-only policies: Three districts' responses to question 2 in Massachusetts. Educational Policy, 19(4), 595-620. doi: $10.1177 / 0895904805278065$

Dinan, J. J. (2007). The original intent and current operation of direct democratic institutions. Albany Law Review, 70(3), 1035-1044.

Donovan, T., \& Bowler, S. (1998). Direct democracy and minority rights: An extension. American Journal of Political Science, 42(3), 1020-1024. doi:10.2307/2991742

DuVivier, K. K. (2007). Out of the bottle: The genie of direct democracy. Albany Law Review, 70(3), 1045-1055.

Dyck, J. J. (2009). Political distrust and conservative voting in ballot measure elections. Political Research Quarterly, 63(3), 612-626. doi:10.1177/1065912909331427

Edwards, D. (1995). A stepping stone to reform: \$100 Campaign rontribution limits. Social Policy, 26(1), 9-11.

Frey, B. S., \& Goette, L. (1998). Does the popular vote destroy civil rights? American Journal of Political Science, 42(4), 1343-1348. doi: $10.2307 / 2991861$

Gamble, B. S. (1997). Putting civil rights to a popular vote. American Journal of Political Science, 41(1), 245-269. doi:10.2307/2111715

Gerber, E. R. (1999). The populist paradox: Interest group influence and the promise of direct legislation. Princeton, NJ: Princeton University Press.

Glaser, B. G., \& Strauss, A. (1967). The discovery of grounded theory. Chicago: Aldine.

Goebel, T. (1997). "A Case of democratic contagion": Direct democracy in the American west, 1890-1920. Pacific Historical Review, 66(2), 213-230. doi: $10.2307 / 3640628$

Goldstone, J. A. (2004). More social movements or fewer? Beyond political opportunity structures to relational fields. Theory and Society, 33(3/4), 333-365. doi:10.1023/B:RYSO.0000038611.01350.30

Hadwiger, D. (1992). Money, turnout, and ballot measure success in California cities. Western Political Quarterly, 45(2), 539-547. doi: $10.2307 / 448725$

Haider-Markel, D. P., Querze, A., \& Lindaman, K. (2007). Lose, win, or draw? A reexamination of direct democracy and minority rights. Political Research Quarterly, 60, 304-314. doi:10.1177/1065912907301984

Hoesly, C. (2005). Reforming direct democracy: Lessons from Oregon. California Law Review, 93(4), 1191-1248.

Howell, S., \& Vanderleeuw, J. (1990). Economic effects on state governors. American Politics Quarterly, 18, 158-168. doi:10.1177/1532673X8001800203

Kaufmann, B., \& Waters, M. D. (2004). Direct democracy in Europe. Durham, NC: Carolina Academic Press.
Kramer, G. H. (1971). Short-term fluctuations in U.S. voting behavior: 1896-1964. American Political Science Review, 65, 131-143. doi: $10.2307 / 1955049$

Landis, J. R., \& Koch, G. G. (1977). The measurement of observer agreement for categorical data. Biometrics, 33, 159-174. doi: $10.2307 / 2529310$

Lewis-Beck, M. (1990). Economics and elections: The major western democracies. Ann Arbor, MI: University of Michigan Press.

Magleby, D. B. (1984). Direct legislation: Voting on ballot propositions in the United States. Baltimore, MD: Johns Hopkins University Press.

Magleby, D. B. (1998). Ballot initiatives and intergovernmental relations in the United States. Publius, 28(1), 147-148. doi:10.1093/oxfordjournals.pubjof.a029945

Matsusaka, J. G. (1992). Economics of direct legislation. Quarterly Journal of Economics, 107(2), 541-571. doi:10.2307/2118481

Matsusaka, J. G. (1995). Fiscal effects of the voter initiative: Evidence from the last 30 years. Journal Political Economics, 103, 587-623. doi: $10.1086 / 261996$

Matsusaka, J. G. (2004). For the many or the few: The initiative process, public policy, and American democracy. Chicago: University of Chicago Press. doi:10.7208/chicago/9780226510873.001.0001

McCuan, D., Bowler, S., Donovan, T., \& Fernandez, K. (1998). California's political warriors: Campaign professionals and the initiative process. In S. Bowler, T. Donovan \& C. Tolbert (Eds.), Citizens as Legislators (pp. 55-79). Columbus, OH: Ohio State University Press.

McLendon, M. K., \& Eddings, S. (2002). Direct democracy and higher education: The state ballot as an instrument of higher education policy making. Educational Policy, 16, 193-218. doi:10.1177/0895904802016001010

McVeigh, R. (1995). Social structure, political institutions, and mobilization potential. Social Forces, 74(2), 461-486.

Miles, M. B., \& Huberman, A. M. (1994). Qualitative data analysis: An expanded sourcebook (2nd ed.). Thousand Oaks, CA: Sage.

Mora, J. K. (2009). From the ballot box to the classroom. Educational Leadership, 66(7), 14-21.

Moses, M. S., \& Saenz, L. P. (2008). Hijacking education policy decisions: Ballot initiatives and the case of affirmative action. Harvard Educational Review, 78(2), 289-310.

Muir, E., \& Schneider, K. (1999). State initiatives and referenda on bonds: A comparative analysis of one solution for the school infrastructure crisis. Journal of Education Finance, 24(4), 415-433

Olsen, L. (2009). The role of advocacy in shaping immigrant education: A California case study. Teachers College Record, 111(3), 817-850.

Page, B. I., \& Shapiro, R. Y. (1992). The rational public: Fifty years of trends in Americans' policy preferences. Chicago: University of Chicago Press. doi:10.7208/chicago/9780226644806.001.0001

Peltzman, S. (1987). Economic conditions and gubernatorial elections. American Economic Review, 77, 293-297.

Schacter, J. S. (1995). The pursuit of "popular intent": Interpretive dilemmas in direct democracy. Yale Law Journal, 105(1), 107-176. doi: $10.2307 / 797141$

Sharum, J. A. (2007). A brief history of the mechanisms of constitutional change in New York and the future prospects for the adoption of the initiative power. Albany Law Review, 70(3), 1055-1088.

Sittig, R. F. (1995). Campaign reform: Interest groups, parties, and candidates. Annals of the American Academy of Political and Social Science, 537, 85-95. doi: 10.1177/0002716295537000008

Skiba-Crafts, A. (2009). Conditions on taking the initiative: The First Amendment implications of subject matter restrictions on ballot initiatives. Michigan Law Review, 107(7), 1305-1336.

Stratmann, T. (2006). Is spending more potent for or against a proposition? Evidence from ballot measures. American Journal of Political Science, 50(3), 788-801. doi:10.1111/j.15405907.2006.00216.x

Straus, A., \& Corbin, J. (1998). Basics of qualitative research. Thousand Oaks, CA: Sage.

The National Commission on Excellence in Education. (1983). A nation at risk. Washington, DC: United States Department of Education.

Tolbert, C. J., \& Smith, D. A. (2005). The educative effects of ballot initiatives on voter turnout. American Politics Research, 33, 283-309. doi: $10.1177 / 1532673 \times 04271904$

Towne, G., Wortley, J., Pratt, E., Margules, S., Carrasco, J., \& Arasim, E. (1994). Michigan school finance reform. Anlyasis of the enacted 
school finance/education reform package. Lansing, MI: Michigan State Legislature.

Whitney, T. N. (1993). Voters and school finance: The impact of public opinion. Denver, CO: National Conference of State Legislatures.

Wilcox, D. F. (1912). Government by all the people New York: MacMillan. 